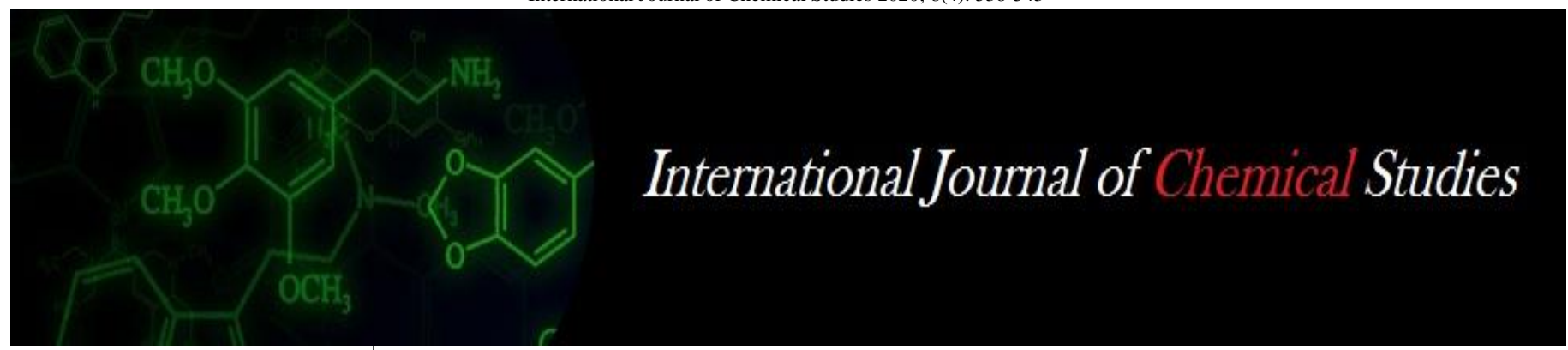

P-ISSN: 2349-8528

E-ISSN: 2321-4902

www.chemijournal.com

IJCS 2020; 8(4): 338-343

(C) 2020 IJCS

Received: 20-05-2020

Accepted: 24-06-2020

Sonali Swagatika

Department of Soil and Water

Conservation Engineering,

College of Agricultural

Engineering and Technology,

Orissa University of Agriculture

and Technology, Bhubaneswar,

Odisha, India

Prabhat Ranjan Khakha

Department of Soil and Water

Conservation Engineering,

College of Agricultural

Engineering and Technology,

Orissa University of Agriculture

and Technology, Bhubaneswar,

Odisha, India
Corresponding Author: Sonali Swagatika

Department of Soil and Water

Conservation Engineering,

College of Agricultural

Engineering and Technology,

Orissa University of Agriculture

and Technology, Bhubaneswar,

Odisha, India

\section{Water auditing of a small watershed: A review}

\author{
Sonali Swagatika and Prabhat Ranjan Khakha
}

DOI: https://doi.org/10.22271/chemi.2020.v8.i4e.9711

\begin{abstract}
Water auditing mainly depends on rainfall analysis and cropping pattern, water balance, watershed development and in-situ moisture conservation. Agriculture is highly dependent on rainfall and many decisions are made based on the amounts of rainfall occurring during crop seasons. The rainfall distribution pattern is most uneven and stochastic, hence knowledge of average annual rainfall is not very useful for deciding the cropping pattern. The watershed development program focus on water, its objective is to enhance crop productivity through in-situ moisture conservation practice.
\end{abstract}

Keywords: Water auditing, rainfall analysis, in-situ moisture conservation, watershed development

\section{Introduction}

Water audit determines the amount of water enters, stores and lost from system. Water audit is the most effective tool for water management. Water audit determines how efficiently the system is operating and where some of losses may be occurring. With the help of water audit, identification and quantification of losses can be possible. It suggest what steps can be taken to reduce the water use and losses (Shruthi et al. 2013) ${ }^{[40]}$

Water audit and its analysis which can not only solve many water related problem but also saves precious resources and public money. It provides decision making tools to utility managers, directors, and operators. i.e. knowing where water is being used in the system that allows to make decisions about investing resources such as time, labor and money. It also allows managers to efficiently reduce water losses in the system (Ganonkar et al. 2013) ${ }^{[13]}$. Water audits provide a rational, scientific framework that categorizes all water use in your system. It is a tool to overcome drought related problem, shortage, leakage and losses (Shruthi et al. 2013; Ganonkar et al. 2013) ${ }^{[40,13]}$.

Water auditing can contribute to sustainable water use, with the ideal outcome of zero liquid discharge (ZLD). This is the concept of closing water cycles so that no water is discharged from a system, meaning that minimal water must be input and then reused and recycled wherever possible (Byers et al.1995).

Comprehensive water audit gives a detailed outline of the water use, there by facilitating easier and effective management of the resources with improved reliability. It helps in correct diagnosis of the problems faced in order to suggest optimum solutions. It is also an effective tool for realistic understanding and the adaptability of the system for future expansion and modernization of system.

\section{Rainfall analysis and crop planning}

Jat et al. (2006) ${ }^{[2]}$ after a study on 'Analysis of Weekly Rainfall for Sorghum based Crop planning in Udaipur region' concluded that chances of drought are more at critical stages of sorghum and there was a scope for in - situ moisture conservation and runoff collection in tanks for supplemental irrigation. Ravi crops are found to be grown under moisture stress.

Audu (2012) ${ }^{[9]}$ in his article on 'A Descriptive Analysis of Rainfall for Agricultural Planning in Lokoja Local Government Area of Kogi State, Nigeria' pointed out that crops which can withstand longer days of absence of rainfall should be planted early such as melon and hybrid crops should be introduced while the use of irrigation should be given an aggressive attention in order to boost crop production, ensure food security and alleviate poverty.

Chinchorkar et al. (2012) ${ }^{[12]}$ in their research article on 'Rainfall characterization and crop planning of scarcity Zone (Zone-II) for Maharashtra state' suggested to grow grasses and dry 
land horticulture viz, custard apple, pomegranate etc. on shallow soil in addition to present cropping pattern. Similarly in medium and deep soils in Kharif season sunflower, pearmillet + pigeonpea, castor, groundnut etc. were suggested. In Rabi sunflower, safflower, Rabi sorghum, gram, etc. were suggested with the provision of supplemental irrigations.

Kingra et al. (2013) ${ }^{[26]}$ viewed in the title on 'Wet and Dry Spell Analysis for Crop Planning in Sub-Mountainous Punjab using Markov Chain Approach' that the from knowledge of rainfall probability analysis, crop sowing dates can be adjusted in such a way that critical stages of the crop coincide with the period of higher rainfall probability. Apart from saving crops from water deficit, insect-pest and disease occurrence can also be predicted based on these sequences of dry and wet spell.

Hadgu et al. (2013) ${ }^{[15]}$ in his article on 'Trend and variability of rainfall in Tigray, Northern Ethiopia: Analysis of meteorological data and farmers' perception' indicated that rainfall in the region is highly variable with a non-significant trend in both annual and seasonal totals for all stations. However, trends of rainfall events such as onset date, cessation date, LGP, and dry spell length were changed significantly in most stations, which agreed with the farmers' perception. Moreover, most stations experienced drought conditions in the last decade. The results suggest the need for designing appropriate agronomic and water management strategies to offset the negative impacts of rainfall variability in the study area.

Roy (2013) ${ }^{[39]}$ in her article on Time Series, Factors and Impacts Analysis of Rainfall in North-Eastern Part in Bangladesh' studied the correlation coefficients between rainfall and time for Sylhet, where correlation coefficient for Sylhet is negative.

Harpalani et al. (2013) ${ }^{[18]}$ in the study on 'Analysis of Rainfall Data and Design of Storm Water Drainage System in an Urban Area' observed that rainfall data available from 1969 to 1983 are with duration of 5,10,15,30,45,60,75,90 minute. And analysis rainfall data is carried for year 1969 to 1983 and one year flood frequency is calculated. Latest rainfall data of 2001 to 2010 are available with duration of 60 minute and other minute's data are found by correlating with past data and one year flood frequency of latest data of 2001 to 2010 is calculated. Rational method is used for estimating runoff from catchment.

Mundetia and Sharma (2014) ${ }^{[32]}$ in the article on 'Analysis of rainfall and drought in Rajasthan state, India' studied the importance of SPI and rainfall indices in understanding the climate change impacts and droughts to provide better assessment and management aspects for the society.

Admasu et al. (2014) [3] in his paper on 'Markov Chain analysis of dry, wet weeks and statistical analysis of weekly rainfall for agricultural planning at Dhera, Central Rift Valley Region of Ethiopia' studied that the rainfall pattern is very important for making decision on crop planning and water management. This study revealed the chance of weeks for appropriate crop planning and water management.

Murumkar and Arya (2014) ${ }^{[33]}$ in his rapporteur's report on 'Trend and Periodicity Analysis in Rainfall Pattern of Nira Basin, Central India' recorded that the Monsoon and postmonsoon seasonal rainfall shows a rising trend while the summer and winter seasonal rainfall shows a falling trend. Wavelet analysis showed prominent annual rainfall periods ranging from 2 to 8 years at all the stations after 1960s resulting in describing more changes in the rainfall patterns after 1960s.

Suhili and Khanbilvardi (2014) ${ }^{[43]}$ had written an article on 'Frequency Analysis of the Monthly Rainfall Data at Sulaimania Region, Iraq' indicate that the Gamma distribution was the one that fits the monthly rainfalls in the three locations with the highest percent, $62.5 \%, 50 \%$, and $37.5 \%$ for Sulaimania, Dokan, and Derbrndikhan respectively. However the normal distribution gives the same percent for the last station. The minimum number of fits are those of the lognormal distribution followed by the weibull and then by the exponential distribution.

Kar et al. (2014) ${ }^{[25]}$ studied on 'Weekly Rainfall Analysis for Crop Planning Using Markov's Chain Model for Kandhamal District of Odisha, India'. This analysis can be helpful to find out different cropping system including intercropping and sequence cropping suitable during that period.

Adeyemo et al. (2014) ${ }^{[2]}$ described in the title on 'Analysis of Temperature and Rainfall Trends in Vaal-Harts Irrigation Scheme, South Africa' that precipitation is maximum in the summer and minimum during winter. Precipitation with highest average of $60 \mathrm{~mm}$ in 1988, and lowest average was 12 mm in 1992.

Hanumant and Karbhari (2014) ${ }^{[17]}$ focused on 'Demands of Changes in Cropping Pattern: A Case Study of Akole Tahasil' observed from the study area, that there is a greater variation in the changes land use and cropping pattern. Farmers have adopt modern technology i.e. fruits and vegetables drip irrigation facility, variety seeds material, increasing use by composting biomass, improved planting technology and micro irrigation systems, crop loans, good network of transports and markets, agricultural advisory centers and also available facilities in the study area. Therefore, recently cropping pattern was change and day by day positive increased.

Amrutha Rani and Shreedhar (2014) ${ }^{[5]}$ have analysed in their research paper on 'Study of rainfall trends and variability for belgaum district' the phenomenon of low rainfall in the district, statistical analysis of annual rainfall data. The analysis was based on the series of tests designed to determine if the annual rainfall data was consistent, random and trend free. The trend in the data was determined by various methods such as Linear regression method etc. The different variability was determined for stations. The Standard Precipitation Index (SPI) method was used in this study to analyze Drought.

Nayak (2015) ${ }^{[35]}$ has analysed in the title on 'Studies on weekly water deficit during different crop growing seasons at Rahuri, India' that Irrigation is of prime importance for assured crop production. This analysis of data may be more useful in better planning of cropping and for water harvesting during monsoon season for effective irrigation during rabi and summer season.

Asim and Satyendranath (2015) ${ }^{[8]}$ investigated in their article on 'Study On Rainfall Probability Analysis At Allahabad District Of Uttar Pradesh' to test the goodness of fit by Chisquare test. It was also clearly indicated that the Gumbel distribution was found to be best model for predicting the annual rainfall $(\mathrm{mm})$. While Log Normal distribution is fairly close to the observed annual rainfall ( $\mathrm{mm})$.

Ray (2016) ${ }^{[38]}$ in the research article on "Rainfall probability analysis for contingent crop planning in Keonjhar" analysed that the $75 \%$ of assured probability level rainfall of more than $250 \mathrm{~mm}$ can be expected only in July and August months and this rainfall is hardly sufficient for meeting the water requirement in upland situations.However at 50 per cent 
probability which is equivalent to average condition. Kumar et al. (2018) "29] "Rainfall probability analysis for contingent crop planning in Jagatsinghpur" also depicted the same.

Arvind et al. (2017) ${ }^{[6]}$ analysed in the article on "Statistical Analysis of 30 Years Rainfall Data: A Case Study", that the study will provide useful information for water resources planner, farmers and urban engineers to assess the availability of water and create the storage accordingly

Vinothkanna (2019) [48] studied in the research paper on "Rainfall probability analysis for strategic and efficient crop planning in Namakkal district, Tamil Nadu" that there should be adequate knowledge to the farmers to help them to take farm level decisions for profitable crop production, for this analysis Weibull's method of probability is used.

\section{Water audit (water balance)}

Water audit is the most effective tool for water management. A water balance or water budget calculation is a method used by hydrologists to assess the water resources within an area, and to verify that the different measurements of hydrological terms are consistent.

Hogstrom and Larsson (1967) ${ }^{[20]}$ on their article on "Studies on water balanceof a small natural catchment area in southern Sweden " analysed that there is a significant and very pronounced pattern of seasonally influenced subsurface inflow and outflow.

Lal (1991) ${ }^{[30]}$ has analysed in the article on "current research on crop water balance and implications for the future" that analysed that the magnitude and dynamics of different components of the crop water balance was crucial to develop the technological options for sustainable management of soil and water resources. The objective of soil and crop management was to increase crop transpiration, plant biomass, and the harvest index.

Ishii et al. (2004b) ${ }^{[21]}$ on their article " Summer water balance in an Arctic tundra basin, eastern Siberia " studied that both the summer rainfall and snowmelt amount were major input components and they shows considerably inter annual variability.

Zhuravin (2004) ${ }^{[50]}$ analysed in the article on "Features of water balance for small mountains watershed in East Siberia" that the river runoff was a predominant discharging component of a water balance, comprising on average $73 \%$ of total precipitation while evaporation was $34 \%$ on average. The water balance aspects of shading and direct illumination of slopes were also considered.

Cheng et al. (2006) ${ }^{[11]}$ on their research article "Estimation of groundwater recharge using water balance coupled with baseflow record estimation and stable base-flow analysis" studied the long term mean annual groundwater recharge with the help of a water-balance approach coupled with the base-flow record estimation and stable-base flow analysis. They studied that the Long-term mean annual groundwater recharge was derived by determining the product of estimated long-term mean annual runoff (the difference between precipitation and evapotranspiration) and the base-flow index (BFI)

Sudhishri et al. (2007) ${ }^{[42]}$ on the title "Water balance studies and strategies for combating water deficit in Upper Kolab catchment of Orissa" studied that the water balance was done according to Thornthwaite book keeping technique.

Ganorkar et al. (2013) ${ }^{[13]}$ on the research article "Water auditA tool for assessment of water loss" concluded that the water audits provide a rational, scientific framework that categorizes all water use in the system. It is a tool to overcome drought related problem, shortage, leakage and losses
Shruthi et al. (2013) [40] found in the article on "Water auditing of Chikmagalur water supply scheme" that water audit was the most effective tool for water management. The performance indicator i.e. infrastructure Leakage Index (ILI) value was calculated as 0.6 , which indicates that the system performance was good as the water supply system was well maintained.

Knobloch and Klingel (2014) ${ }^{[27]}$ discussed on the article "Automated water balance calculation for water distribution systems" that water balance components was implemented in a GIS-based tool.

Parmar et al. (2014) ${ }^{[36]}$ studied in their article on "Alternative cropping possibilities for rainfed crop based on length of growing period driven by web user interface" that the crop growth and yield of rainfed crop was dependent on rainfall amount and soil moisture status in the root zone. The water balance climatology of any rainfall region helps in selecting crops and cultivars for better net return. Inadequate information on this aspect sometimes failed to rationalize the natural resources

Abounoori (2015) [1] estimated in the title "Analysis the economics of water- budget in tehran using the Thornthwaite's" that the intensity and frequency of drought reduces the injurious effect of drought. This also focus that the water-budget methods and Thornthwaite's aridity index and its standard deviation was employed to show the frequency and intensity of drought effects.

Kulkarhi et al. (2015) ${ }^{[28]}$ observed in the title "Water audit: a case study of water supply scheme of shrivardhan" that the comprehensive audits can give the utility a detailed profile of the water supply system and water users, allowing easier management of resources and improved reliability. It is an important step towards water conservation and, if linked with a leak detection plan, can save the utility a significant amount of money and time.

Hamdan (2018) [16] in the article on "Auditing Water Management to Achieve Sustainable Development in Supply Chain" concluded a set of conclusions the most important of which are the following: water reserves are not being maintained, efficient use of water has not been achieved due to high rates of water withdrawn from surface water, nonprovision of safe drinking water and appropriate sanitation, inequality of water provision between country and urban population, low rate of wastewater treatment, most wastes of various activities are disposed of by being dumped in rivers untreated and high rate of morbidity resulting from water pollution. Despite the efforts exerted either by projects and plans or water related conventions, no effect has been seen on water management reality to achieve SD. (economic, social, environmental and institutional)

\section{Watershed development}

Watershed management is a practice of managing human activities on a watershed by recognizing the interrelationships among land use, soil and water as well as the linkage between uplands and downstream areas. Watershed development is a useful for sustainable development of any region. The previous work done by the researchers in analysis of watershed development is presented here.

Batchelor et al. (2003) [10]. In the article on "Watershed development: A solution to water shortages in semi-arid India or part of the problem" proves that Water audits had no evidence to suggest that traditional watershed development activities had halted degradation of water resources or made villages less susceptible to the shock of drought. Intensive 
water harvesting has altered the spatial and temporal pattern of availability and access to surface and ground water resources.. It was quite clear that 'traditional' watershed development was not going to lead to sustainable or equitable development of natural resources. Watershed development that was biased towards the management of water resources had long-term potential, if it was carried out in an appropriate policy environment and if a modified approach to watershed development receives widespread political and public support. Swami and Kulkarni (2011) ${ }^{[44]}$ in the article on "Watershed management - A means of sustainable development - A case study" observed that where large amount of rainwater is there it was directed to recharge ground water resources. Hence it was planned to take such engineering and biological measures that direct this extra runoff to ground water storage. Moreover it was used to tackle the issue of flood which mainly occurs due to excess runoff.

Unde and Telore (2012) ${ }^{[47]}$ studied in the research paper on "Role of watershed development programme in sustainable development:Nidhal experience from Satara District, Maharashtra" that the Watershed was a hydrologic unit which was used for the management and planning of natural resources. Watershed development was a need of hour for sustainable water resource development and management of rain shadow region.

\section{In-situ Conservation}

Hiremath et al. (2002) ${ }^{[19]}$ in the article on "Water balance studies in small catchment area of paleozoic rock using environmental isotope tracer techniques" studied that among in situ moisture conservation practices, tied ridges and compartment bunding found beneficial in conserving higher soil moisture which reflected in getting higher biomass (7.02 an $6.62 \mathrm{t}$ ha-1) and $\mathrm{N}$-accumulation (101.79 and $92.68 \mathrm{~kg}$ ha1) in sunnhemp. The grain yield of sorghum grown after sunnhemp green manuring was significantly higher in tied ridges (22. $10 \mathrm{q}$ ha-1) and compartment bunding (21.24 q ha1) than in- flat bed method (14.05 q ha-1). Among the levels of nitrogen to rabi sorghum, application of $25 \mathrm{~kg} \mathrm{~N}$ ha-1 to sorghum along with sunnhemp incorporation recorded grain yield of $19.48 \mathrm{q}$ ha-1 which was on par with sunnhemp green manuring with recommended dose of $50 \mathrm{~kg} \mathrm{~N}$ ha-1 $(21.05 \mathrm{q}$ ha-1). The economics of sunnhemp-sorghum sequence revealed that higher incremental net returns and $\mathrm{B}: \mathrm{C}$ ratio were recorded with tied ridges and compartment bunding in sunnhemp along with application of $25 \mathrm{~kg} \mathrm{~N}$ ha-1 to sorghum. Muthamilselvan et al. (2006) in article "In situ moisture conservation techniques in dry farming" revealed that jalshakti (hydrophilic polymer) in furrows at sowing + mulch combination was the best one in terms of maximum yield, soil moisture content and water use efficiency in the rainfed mustard crop. In a study, the basin lister resulted in an increased crop yield of 11.0 per cent as compared to conventional method of summer ploughing. The broad bed andfurrows result in larger moisture storage than the other tillage methods. In a study, there was 13.45 per cent increase in yield in broad bed and furrow system over the flat bed method of sowing. It was reported in another study that there was 11.67 per cent increase in yield of ragi in the ridge and furrow system over the flat method of sowing, it was also was reported that compartmental bunding increases the grain and fodder production of rabi sorghum by 38 and 50 per cent respectively.

Kannan et al. (2007) ${ }^{[24]}$ in the article "Analysis of soil moisture conservation techniques with dry season maize crop on hill land at rubirizi, Rwanda.Germany" indicates that it was inevitable to provide supplemental irrigation and in-situ moisture conservation for successful crop in this region. Bench terrace increased the average soil moisture content in $90 \mathrm{~cm}$ soil depth by more than $50 \%$ than that of unterraced land. This indicates that in-situ moisture conservation measures are effective to increase soil moisture compared to plain bed. Performance of ridges \& furrows, compartmental bund and plain land was evaluated in terms of soil moisture conservation. The study reveals that compartment bund performed well in both $30 \mathrm{~cm}$ and $60 \mathrm{~cm}$ soil depths followed by ridges $\&$ furrows because of consistent soil moisture as evidenced by less coefficient of variation Plain bed (control) exhibited lowest degree of fluctuation of deficit water indicating poorly influenced by rain fall as compared to ridges $\&$ furrows and compartmental bunding. In terms of efficiency of moisture conservation during the cropping period, ridges \& furrows performed well with $85.8 \%$ followed by compartmental bunding with 75.9 per cent in terraced field.

Gebreegziabher et al. (2008) ${ }^{[14]}$ studied in the research article "Contour furrows for in-situ soil and water conservation, Tigray, Northern Ethiopia " that permanent raised beds with contour furrows at $60-70 \mathrm{~cm}$ interval treatments, were considered and evaluated as practices that could increase the efficiency of in situ water utilization and soil conservation. Permanent raised beds with contour furrows at $60-70 \mathrm{~cm}$ interval significantly $(P<0.05)$ reduced runoff volume, runoff coefficient and soil loss as compared to traditional ploughing Moreover, the use of permanent raised beds if combined with crop mulching and crop diversification was an important component for the development of sustainable conservation agriculture practices in the region.

Allolli et al. (2008) ${ }^{[4]}$ studied in their article "Influence of insitu moisture conservation practices on the performance of Dryland Cluster Bean" that the Ridge and furrows along with mulch enhanced the vigour of the crop as manifested in higher plant height, leaf area and dry matter production. Further moisture conservation practices (ridges and furrow + mulch) helped to promote the productivity of cluster bean as evident in significantly higher yield per unit area. The pooled data indicated the higher yield (30.41 q/ha) due to ridges and furrows + mulch followed by ridges and furrows as compared to flatbed method $(24.63 \mathrm{q} / \mathrm{ha})$ of cultivation. Further, ridges and furrows + mulch resulted in higher moisture retention in the soil as compared to flatbed method of cultivation.

Malligawad (2010) ${ }^{[31]}$ in the article on "Studies on the effect of in-situ soil moisture conservation and nutrient management practices on the productivity of seasame and sorghum in sequencer cropping system" observed that sesame crop showed a similar response to different planting methods. 2:1 or 3:1 skip row method of planting + opening of furrow in skipped row 20 days after sesame sowing alone or with INMP or NMP with application of organic manures to the preceding crop of sesame resulted in higher seed yield of sorghum. Insitu soil moisture conservation through $2: 1$ or $3: 1$ skip row method of planting along with application of either organic manures or organic manures + inorganic fertilizers to preceding sesame crop and no organic manures and no inorganic fertilizers to succeeding sorghum produced higher yields of both the sesame and sorghum crops in this system. Patil and Taley (2013) ${ }^{[37]}$ in the article "Impact of in situ soil and water conservation measures on water use and production efficiency for cotton" concluded that the increase in productivity was 38.26 per cent over along the slope cultivation followed by rest of the treatments. The treatments 
are viz., cultivation along the slopes (T1), cultivation along the slope with opening of tide furrow (30 DAS) (T2), cultivation across the slope with opening of alternate furrow (30 DAS) (T3), cultivation across the slope with ridges and furrows (30 DAS) (T4), contour cultivation with opening of alternate furrow (30DAS) (T5), contour cultivation with opening of ridges and furrows (30 DAS) (T6).

Taley (2014) focused in the article on "Evaluation of in-situ Soil and Moisture Conservation Methods on Runoff, Soil, Soil \&Nutrients Loss and Productivity of Jower Crop" and observed that Productivity of Jowar was favorably influenced by treatment T7. Highest grain yield $11.20 \mathrm{q}$ ha-1 was recorded in treatment $\mathrm{T} 7$ followed by treatment $\mathrm{T} 6, \mathrm{~T} 5, \mathrm{~T} 4, \mathrm{~T} 3, \mathrm{~T} 2$ and $\mathrm{T} 1$. Water use efficiency was more dominant in treatment $\mathrm{T} 7$ i.e. $1.41 \mathrm{Kg}$ ha- $1 \mathrm{~mm}-1$ followed by 1.29 (T6), 1.25 (T5), 1.21 (T4), 1.13 (T3), 1.09 (T2) and 1.04 in treatment T1.Data regarding soil moisture content at various depth viz., $15 \mathrm{~cm}, 30 \mathrm{~cm}, 45 \mathrm{~cm}$, and $60 \mathrm{~cm}$ shows that highest moisture content at all depth was found in treatment T7. There was total seven treatments viz. along the slope cultivation (T1), along the slope cultivation with opening of tide furrow (T2), across the slope cultivation with sub surface tillage (T3), across the slope cultivation with opening of alternate furrow with sub surface tillage (T4), Across the slope cultivation with opening of ridges and furrow (T5), Contour cultivation with opening of alternate furrows (T6) and Contour cultivation with opening of ridges and furrows (T7).

Zegeye (2016) ${ }^{[49]}$ in the title "In situ and ex situ conservation: Complementary approaches for maintaining biodiversity" concluded that conservation of biodiversity is achieved by two approaches - in situ and ex situ. In order to ensure the maintenance of biodiversity, there is a need to employ complementary in situ and ex situ conservation. There is also a need to prioritize ecosystems, species and populations for conservation actions.

\section{Conclusion}

It is evident from this brief discussion that all the parameters i.e rainfall analysis and cropping pattern, water balance, watershed development and in-situ moisture conservation plays an important role in water budgeting.

\section{References}

1. Abounoori A. Analysis the economics of water- budget in tehran using the Thornthwaite's.Indian J. of Fundamental and Applied Life Sci, 2015. ISSN.5(S1):1000-1007.

2. Adeyemo J. Fred Otieno and OlumuyiwaOjo. Analysis of temperature and rainfall trends in vaal-harts irrigation scheme, South Africa. American J of Engineering Res. 2014; 3(2):265-269.

3. Admasu W, Kassu Tadesse, Fitsume Yemenu, Birhan Abdulkadir. Markov chain analysis of dry, wet weeks and statistical analysis of weekly rainfall for agricultural planning at Dhera, Central Rift Valley Region of Ethiopia. African J. of Agril. Resh. 2014; 9(29):22052213.

4. Allolli TB, UK Hulihalinand, SI Athani. Influence of insitu moisture conservation practices on the performance of Dryland Cluster Bean. Karnataka J Agric. Sci. 2007; 21(2):2250-252

5. Amrutha Rani HR, R Shreedhar. Study of rainfall trends and variability for Belgaum district. Int. J. of Res. in Engineering and Tech. 2014; 3(6):148-155.
6. Arvind G, PA Kumar, S Girish Karthi, CR Suribabu. Statistical Analysis of 30 Years Rainfall Data: A Case Study. Earth and Environmental Science, 2017.

7. Asati SR. Analysis of rainfall data for drought investigation at Brahmapuri. Int. J. Life Sci. Bt and Pharm. 2012; 1(4):81-86.

8. Asim M, Satyendranath. Study on rainfall probability analysis at Allahabad District of UP. J. of Bio., Agriculture and Healthcare. 2015; 5(11):214-222.

9. Audu EB. A descriptive analysis of rainfall for agricultural planning in Lokojalocal government area of Kogi State, Nigeria. International Journal of Science and Technology. 2012; 2(12) 850-855.

10. Batchelor $\mathrm{CH}$, MS Rama Mohan Rao, SM Rao. Watershed development: A solution to water shortages in semi-arid India or part of the problem. Land Use and Water Resources Res. 2003; 3:1-10.

11. Cheng H, Wei-Ping Chen Wei, Huang Lee. Estimation of groundwater recharge using water balance coupled with base-flow-record estimation and stable-base-flow analysis. Environ Geol. 2006; 51:73-82.

12. Chinchorkar SS, FG Sayyad, GR Patel, SK Patel, BK Yaduvanshi. Rainfall characterization and crop planning of scarcity Zone (Zone-II) for Maharashtra state Int. J Agric. Engg. 128. 2012; 5(2):127-132.

13. Ganorkar RA, PI Rode, SA Deshmukh, RM Dhoble. Water audit- A tool for assessment of water loss. Int. J. of Computational Engineering Res. 2013; 3(3):252-256.

14. Gebreegziabher TJ, Nyssen B, Govaerts F, Getnet M, Behailu M, Haile $\mathrm{J}$ et al. Contour furrows for in-situ soil and water conservation, Tigray, Northern Ethiopia. Soil and Tillage Res. 2009; 103:257-264.

15. Hadgu G, K Tesfaye, G Mamo, B Kassa. Trend and variability of rainfall in Tigray, Northern Ethiopia: Analysis of meteorological data and farmers perception. Academia J. of Agril. Res. 2013; 1(6): 88-100.

16. Hamdan KH. Auditing Water Management to Achieve Sustainable Development in Supply Chain. International Journal of Supply Chain Management. 2018; 7(5):697710.

17. Hanumat MP, TB Karbhari. Demands of changes in cropping pattern: A case study of Akola Tahasil(M.S, India). Int. J. of Sci. and Res, 2012, 2319-7067.

18. Harpalani PD, RB Khasiya, PG Agnihotri. Analysis of rainfall data and design of storm water drainage system in an urban area. 2013; 2(4):100-104.

19. Hiremath A, J Koll, P Maloszewski. Water balance studies in small catchment area of paleozoic rock using environmental isotope tracer techniques. IAHS Publ. No. 2002; 156:111-124.

20. Hogstrom U, I Larsson. Studies on the water balance of a small natural catchment area in southern Sweden. Tellus. 1967; 20(4):633-641.

21. Ishii Y, Y Kodama, N Sato, H Yabuki. Summer water balance in an Arctic tundra basin, eastern Siberia. IAHS press, Wallingford, U.K. 2004b; 290:177-188.

22. Jat ML, RV Singh, JK Balyan, LK Jain, RK Sharma. Analysis of weekly rainfall for sorghum based crop planning in Udaipur region. Indian J.Dryland Agric. Res. \& Dev. 2006; 21(2):114-122.

23. Jaybhaye PR, Patil VS. Impact of rainfall productivity of rice yield at igatpur. J of MaharastraAgril Uni. 2005; 31(1):115-117.

24. Kannan N, T Senthivel, AJ Rayar, M Frank. Analysis of soil moisture conservation techniques with dry season 
maize crop on hill land at rubirizi, Rwanda.Germany, 2007, 428-436.

25. Kar SK, DP Sahoo, CR Subudhi. Weekly rainfall analysis for crop planning using Markov's Chain model for Kandhamal district of Odisha, India. Int. J. of Engineering Research and Applications. ISSN: 2014; 4(9):139-145.

26. Kingra PK, K. Gill, Sompal Singh. Wet and dry spell analysis for crop planning in sub-mountainous Punjab using Markov Chain Approach. Journal of Agricultural Physics. 2013; 13(2):193-202.

27. Knobloch ANG, P Klingel. Automated water balance calculation for water distribution systems. Karlsruhe Institute of Technology (KIT), Institute for Water and River Basin Management, Kaiserstrabe 12, 76137 Karlsruhe, 2014.

28. Kulkarni AA, AA Patil, BB Patil Water audit: A case study of water supply scheme of shrivardhan. Journal of Computing Technologies. 2015; 3(6):2278-3814.

29. Kumar B, A Baliarshingh, S Jain. Rainfall probability analysis for contingent crop planning in Jagatsinghpur (Odisha). Int. J. of Chemical Studies. 2018; 6(4):461-464.

30. Lal R. Current research on crop water balance and implications for the future. Soil Water Balance in the Sudano-Sahelian Zone. IAHS Publ. no, 1991, 199.

31. Malligawad LH. Studies on the effect of in-situ soil moisture conservation and nutrient management practices on the productivity of seasame and sorghum in sequencer cropping system. CDROM, 2010, 289-292.

32. Mundetia N, Sharma D. Analysis of rainfall and drought in Rajasthan state, India Global NEST J. 2014; 16(10):20-20.

33. Murumkar AR, DS Arya. Trend and Periodicity Analysis in Rainfall Pattern of Nira Basin, Central India. American journal of Climatic Change, 2014, 60-70.

34. Muthamilselvan M, R Manian, K Kathirvel. In situ moisture conservation techniques in dry farming - A review. 2006; 27(1):67-72.

35. Nayak AK. Studies on weekly water deficit during different crop growing seasons at Rahuri, India. Int. J. of Sci. Engineering and Tech. Res. 2015; 4(40):1022-1030.

36. Parmar RS. YR Ghodasara, GJ Kamani, KV Patel. Alternative cropping possibilities for rainfed crop based on length of growing period driven by web user interface. Int. J. Recent and Inno. Trends in Computing and Communication, 2014; 2(5):1260-1265.

37. Patil SS, SM Taley. Impact of in situ soil and water conservation measures on water use and production efficiency for cotton. 2013; 6(2):444-448.

38. Ray. Rainfall probability analysis for contingent crop planning in Keonjhar (Odisha). Asian. $\mathbf{J}$ of Environmental Sciences. 2016; 11(1):106-110.

39. Roy M. Time series, Factors and Impacts Analysis of Rainfall in North-Eastern part in Bangladesh. Int. $\mathbf{J}$ of Scientific and Research Publications. 2013; 3(8).

40. Shruthi CG, NS Sathisha, P Jeevitha. Water auditing of Chikmagalur water supply scheme. J. of Environmental Sci., Computer Science and Engineering \& Technology. 2013; 2(4):088-1093.

41. Subash N, Alok K Sikka, A Abdul Haris. Markov chain approach dry and wet spell rainfall probabilities for ricewheat planning. Indian J. Soil Cons. 2009; 37(2):91-99.

42. Sudhishri S, A Dass, NK Paikaray. Water balance studies and strategies for combating water deficit in Upper Kolab catchment of Orissa. Hydrology Journal, 30 (3-4),
Central Soil and Water Conservation Research and Training Institute, Research Center, PB No,12, Sunabeda-2, Koraput(Orissa), 2007, 103-116.

43. Suhil RH, Khanbilvardi R. Frequency Analysis of the Monthly Rainfall data at Sulaimania Region, Iraq. American Journal of Engineering Research. 2014; 3(5):212-222.

44. Swami VA, SS Kulkarni. Watershed management - A means of sustainable development - A case study. Int. J. of Engineering Sci. and Tech. 2011; 3(3):2105-2112.

45. Taley SM. Evaluation of in-situ Soil and Moisture Conservation Methods on Runoff, Soil, Soil \&Nutrients Loss and Productivity of Jower Crop. 2014; 3(2):186189.

46. Tyagi SK, PS Datta, Ravender Singh. Need for proper water management for food security. Current science. 2012; 102(5):10.

47. Unde MG, NV Telore. Role of watershed development programme in sustainable development:Nidhal experience from Satara District, Maharashtra. Proceeding of International Conference SWRDM, 2012, 68-71.

48. Vinothkanna S. Rainfall Probability Analysis for strategic and efficient crop planning in Namakkaldistrict, Tamil Nadu. Research review Journal. 2019; 4(6):188-190.

49. Zegeye H. In situ and ex situ conservation: Complementary approaches for maintaining biodiversity. Int. J. Research in Environmental Studies, 2016. ISSN 2059-1977

50. Zhuravin S. Features of water balance for small mountainous watershed in East Siberia: kolyma water balance station case study.IAHS Publ. 290: IAHS press, Wallingford, U.K, 2004, 177-188. 